\title{
中国出稼ぎ農村における農地流動化の特徵と展望
}

一黒龍江省鶏西市 $H$ 村の事例から一

\author{
李英花（新潟大学大学院） \\ 伊藤 亮司（新潟大学農学部） \\ 青柳斉(新潟大学農学部)
}

\section{Liquidization of the Farmlands Located in Chinese Farming Villages Vacated by Migrating Citizens: A Study of Village H, Jixi City, Heilongjiang Province}

\author{
Yinghua Li (Graduate School of Science and Technology, Niigata University) \\ Ryoji Ito (Faculty of Agriculture, Niigata University) \\ Hitoshi Aoyagi (Faculty of Agriculture, Niigata University)
}

An analysis of a case study involving village $\mathrm{H}$ in Heilongiiang Province produced the following results with regard to the liquidization of the farmlands located in the minority Korean farming villages and diversification in the scale of agricultural activities. First, in a labor market where employment opportunities are scarce, restrictions on ethnic Korean citizens regarding travel to Korea have been loosened, leading to a surge in ethnic Korean migrant laborers. This has brought about an increase in the lending of land usage

\section{1. 問題意識と課題}

中国に和ける個別農家間の農地使用権の貸借につ いて, 農業部『全国農村社会経済典型調査数据彙編 （1986-1999 年)』（標本調査）によれば, 個別農家 の耕地面積に占める借地 (転包) 面積の比率は, 93 年 $2.4 \%, 96$ 年 $3.6 \%, 99$ 年 $4.7 \%$ と上昇した. そし て，2007 年に実施した第 2 回農業センサスでは $11.2 \%$ になる（実績值は 06 年）。省別では, 上海 $28.4 \%$, 黒竜江 $28.0 \%$, 浙江 $24.7 \%$, 福建 $22.0 \%$ が 特に高い。また，村内に打貸出農家割合では， 全国平均 6.9\%に対して, 上海 $32.4 \%$, 浙江 $26.2 \%$, 北京 $21.7 \%$, 福建 $20.8 \%$ が突出している. このょう な農地流動化率の地域間格差に関して, 山本 [1] や史・買 [3] らは兼業機会の希少性に着目して, 在宅兼業機会に恵まれた浙江省で高く, 地域労働市 場が狭险な山西省で低いことを検証している.また, rights. On the other hand, in neighboring village $\mathrm{T}$, where each household administers only a small plot of land, there are numerous farming households harboring a latent desire to expand the scale of their activities by renting out land. These borrowing and lending activities have encouraged the liquidization of the farmlands located in villages, leading numerous ethnic Korean farmers to vacate their land and creating upper-class farming households.

洪 ４］馮鋒ら［9］は, 出稼ぎ農村における農地 流動化率の高さを指摘した。

以上のように, 中国でも傾向的に及び一部地域で 農地利用権の流動化が進展して扣り, その意味では 農業経営規模の階層変動を予想させる. 但し, 池上 [5] 及び菅沼 [6] は, 貴州省, 湖南省, 安徽省, 四 川省内の 4 か村に抢ける $92 \sim 94$ 年と $2001 \sim 02$ 年 の間の階層変動を検討して，世帯員数の増減に応じ た経営面積の周期的変動を確認し (池上 [5], p. 56), 出稼ぎとって農地利用権の貸借は増大している が，農業経営の分化は一般化できないと言う（菅沼 [6], p. 75). 同様に, 06 年に河南省の出稼ぎ農村を 対象とした李豊ら [8] の事例研究も, 請負地の均分 相続制の下で, 家族構成のライフサイクルに規定さ れた経営規模の周期的变動を析出する。また, 張・史 ［7］は，浙江省の農村固定観察点約 1 千戸を対象と 
した 1986 年から 99 年までの階層変動分析で，下層 (3 畧未満) と上層（10 畧以上）の減少に対して中層 （3～5 畧）の増大を指摘した（1 畧は $6.7 \mathrm{a})$.

以上の「中間層上限」論飞対して, 最近, 董・菅 沼 [2] は, 黒竜江省内の朝鮮族農村 37 戸の農家調査 により, 農地の貸借関係や借地農家の規模拡大条件 について検討し, 農地流動化の顕著な進展による規 模階層の分化を示した. 但し, 貸し手農家の属性分 析が弱いため, 帰村する内陸西部の出稼ぎ兼業農家 とは異なって, 朝鮮族農家の挙家離村志向の出稼ぎ 形態が農地流動の拡大と関係している点は言及され ていない。

そこで，本論文では，黒竜江省内の鷄西市・永豊 朝鮮族郷・ $\mathrm{H}$ 村を事例として，主に貸し手及び借り 手双方の農家経済・経営分析から, 朝鮮族出稼ぎ農 村に打ける農地流動化の背景と規模階層変動の展望 を明らかにしたい。調査時点（2010 年 6 月，9月） での $\mathrm{H}$ 村の農地流動化率は, 面積対比で $95 \%$ と極 めて高い.

\section{2. 事例村の概況}

事例村のある鶏西市は，黒竜江省の東南にあり， 牡丹江市と七台河市に隣接し, 市内は 6 区・2市・ 1 県の行政に分か氺ている. 調查対象の $\mathrm{H}$ 村は, 城 子河区・永豊朝鮮族郷にあって, 郷内 3 つの朝鮮族 村の 1 つである. $\mathrm{H}$ 村の戸籍上の世帯及び人口は, 274 戸， 1,064 人であり，朝鮮族住民が村内人口の 98\%を占める。但し，実際に在住している世帯・人 口は, 90 戸 (全戸の $32.8 \%$ ), 278 人（全人口の 26.0\%) 飞すぎない，その他は，出稼ぎ・進学等で の転出者であり, 韓国への出稼ぎ者が約 6 割を占め るという。韓国への出稼ぎは, 1992 年の「中韓修 交協定」の締結を契機に, 朝鮮族籍農民の韓国への 合法的渡航が容易になり，村内では 93 年頃から増 え始めたという。

村内の耕地面積は 300 ha で水田が 272.5 ha を占 める. 1998 年の請負地再配分のさい, 世帯員数に応 じた農地配分方法（口糧田制）で 1 人当たり 20 a 配分し, 以後の配分調整は無い。また, 村内農家の 貸地面積は 258.7 ha であり, 水田耕作面積の $95 \%$ を占める。他方，村内在住の稲作農家は 17 戸で耕 作面積 45.6 ha（うち借地 31.8 ha）にすぎず，農地利 用権の借り手は村外者が貸地面積の約 8 割を占め,
その大半は隣接する鶏東県 $\mathrm{T}$ 村（漢民族村）の農 民である。

村外者借地の実態について，村民委員会では一部 しか把握していない，村民委員会仲介の契約実績は 49 件（53 ha）にすぎないが，その借り手は T 村 43 戸と長青郷の 2 戸である. 契約期間は $3 ・ 4$ 年が 6 割 と過半で, $1 ・ 2$ 年が 3 割, 5 年以上は 1 割くらいた という。転包費は, $95 \sim 06$ 年は 2,600 元/ha で横ば いであったが, $07 ・ 08$ 年 3,000 元， 09 年以降 4,500 元といらょらに, 最近は上昇傾向にある。これには, 米価の上昇や農地利用権の貸し手市場化が影響して いる.

調査対象農家は，貸し手農家が 21 戸，借り手農家 が 14 戸である．但し，貸し手・借り手双方とも調査 対象者が村内在住農家に偏っている。貸し手農家の 場合, 約 3 分の 2 は不在農家であり，他方，借り手の 多くは村外農家である。不在農家や村外農家に対寸る 直接のヒアリングは困難であったため，事例村内の在 住農家が主な調査対象となった．以下，それぞれの属 性や農家経済の特徵について検討してみよう。

\section{3. 貸し手農家の属性と挙家離村志向}

表 1 に見るよらに，21 戸の戸籍上の世帯員数 82 人のらち, 在村者は 26 人だけで, 村外への出稼ぎ 者が 45 人, 大学等進学転出者が 11 人いる ${ }^{1)}$. また, 夫婦出稼農家が 7 戸，全員転出が 6 戸あり，出稼ぎ 無しは 1 戸のみである，出稼ぎ先では，韓国 22 人 と国内大都市 22 人に分かれる.

親世代の学歴では小学卒 6 人, 中学卒 21 人, 高 校卒 14 人となる。これに対して，子弟の高学歴化 が進んで打り，中卒 10 人及び在学中 2 人，高卒 10 人及び在学中 2 人, 大卒 1 人及び在学中 9 人である. 本村が地方都市から遠隔の純農村であることを考慮 すると，その大学進学率は極めて高いと言えよう。

また，請負農地の貸出（転包）状況について見て みよう。まず， 1 戸当たりの請負面積は $0.6 \sim 1.7$ ha に分散し， 1 ha 前後が大多数である。農地利用権の 貸出先では，村内農家 6 戸（らち $\mathrm{T}$ 村からの転住 3 戸）と $\mathrm{T}$ 村在住の漢民族農家 19 戸であり，転住農 家をも含めると大部分が隣村（T村）出身農家であ る. 貸出先の農家数では 1 戸が多く, 複数貸出農家 は4 戸に留まる。貸借の契約期間では毎年契約が 15 戸と最も多く, 5 年 5 戸， 6 年が 1 戸にすぎない. 
貸出期間では $10 \sim 11$ 年が 9 戸と最も多く, 5 年以 下が 6 戸， 12 年以上が 4 戸， $6 \sim 9$ 年が 2 戸である. 韓国出稼ぎの増大とともに, 本村では 90 年代末頃 に貸借が急増したと言える，そして，出稼ぎ期間が 10 年以上に及ぶ長期稼ぎが多く，農繁期に帰村す る例は大学在学中の省内転出者に希にいる程度だと いう，特に朝鮮族農民の場合，妻子を村に残しなが ら, 数年間以上一度も帰村 (帰国) しない長期出稼 ぎ者が少なくない。また, 年間の転包費 (小作料) は, いずれの農家も 450 元 $/ 10$ a で，支払い方法では現 金が 15 戸と多く，現物 1 戸，現物及び現金が 5 戸 といら回答を得た。 そのさい，一括払いは 4 戸と少 なく，大半が各年払いである.

次に, 貸し手農家の収入構成を見てみよう。まず， 在住農家 15 戸（表中の no. $7 \sim 21 ） の ら ち$, 出稼 ぎ者からの仕送りに依存する無職世帯が大多数を占 め, 仕送りの無い自営農家が 3 戸（No. 7，16，21） いるのみである. 在住農家の家庭収入源の内訳を詳 しく見ると,「出稼者からの仕送りのみ」が 6 戸,「仕 送り＋転包費」5戸，「仕送り＋転包費＋その他」 1 戸，「転包費 + 自営収入」 3 戸となる。 09 年の転
包費は 1 ha 当たり 4,500 元であり，仕送り無しの自 営農家 3 戸（no. 7，16，21）の場合，収入源として の意義は大きい. no. 7 は 40 ・ 50 才代夫婦世帯であ るが，菓子店経営の収入約 5 千元に対して転包費 3,600 元は小さくない. no. 16 は 60 才代夫婦と 30 才代長男の在住世帯であり, 農機具修理業の収入約 1 万元と転包費 4,500 元が主な収入である。また， no. 21 は 50 才代夫婦で, 夫の村長給与に加えて, 水飴店経営の収入 2 万元と転包費 6,750 元が主な収 入である. 他の仕送り世帯でも，約 1 ha の小作料 収入 4,500 元の意義は小さくないであろう。その金 額は，『中国統計年鑑』によれば，08 年の黒竜江省 に打任る農村住民 1 人当たり年間平均純収入 4,856 元にほぼ匹敵する，現時点では，請負地の転包費収 入は，貸し手農家の村在留者の生計にとって，程度 の差あれ重要な収入源と言えよう。

また，アンケートで，農地保有の意識や貸出理由 を聞いてみた。まず,請負農地配分の意義としては, 前述の転包費収入の経済的意義の大きさを反映して 「家計収入の補助」が 8 戸と最も多く，以下，「生計 の最低保障」 7 戸, 「食糧の確保」4 戸, 「財産的価値」

表 1. 貸し手農家の出稼ぎ・転出等の状況

\begin{tabular}{|c|c|c|c|c|c|c|c|c|c|c|}
\hline \multirow{2}{*}{$\begin{array}{l}\text { 農家 } \\
\text { 番号 }\end{array}$} & \multirow{2}{*}{$\begin{array}{l}\text { 家族 } \\
\text { 成員 }\end{array}$} & \multicolumn{6}{|c|}{ 年齢別の世帯構成 ( $\mathbf{\Delta}$ は出稼ぎ者, かっこ内はその数・属性) } & \multirow{2}{*}{$\begin{array}{l}\text { 出稼 } \\
\text { ぎ者 }\end{array}$} & \multirow{2}{*}{$\begin{array}{c}\text { 市外 } \\
\text { 進学者 }\end{array}$} & \multirow{2}{*}{$\begin{array}{l}\text { 在住 } \\
\text { 者数 }\end{array}$} \\
\hline & & 20才未満 & 20才代 & 30才代 & 40才代 & 50才代 & 60才以上 & & & \\
\hline no. 1 & 4 & & $2 \mathbf{\Delta}$ (女1) & & $1 \mathbf{\Delta}$ (妻) & $1 \mathbf{\Delta}$ (夫) & & 3 & 1 & 0 \\
\hline no. 2 & 4 & & 2 & & $1 \mathbf{\Delta}$ (妻) & $1 \mathbf{\Delta}$ (夫) & & 2 & 2 & 0 \\
\hline no. 3 & 3 & 1 & & & $2 \mathbf{\Delta}$ (妻) & & & "2 & 1 & 0 \\
\hline no. 4 & 4 & & 2山 (男1) & & $1 \mathbf{\Delta}$ (妻) & $1 \boldsymbol{\Delta}$ (夫) & & 3 & 1 & 0 \\
\hline no. 5 & 3 & & $1 \mathbf{\Delta}($ 女) & & 2 \(夫婦) & & & 3 & 0 & 0 \\
\hline no. 6 & 4 & & 2山(男2) & & & 2\ (夫婦) & & 4 & 0 & 0 \\
\hline no. 7 & 4 & & 2山 (男2) & & 1 & 1 & & 2 & 0 & 2 \\
\hline no. 8 & 5 & & & 3山(男2女) & & & 2 $\mathbf{\Delta}$ (夫1) & 4 & 0 & 1 \\
\hline no. 9 & 5 & 1 & & 2ム (男女) & & & 2 & 2 & 0 & 3 \\
\hline no. 10 & 4 & & 1 & & $2 \boldsymbol{\Delta}$ (夫婦) & & 1 & 2 & 1 & 1 \\
\hline no. 11 & 3 & & 1 $\boldsymbol{\Delta}$ (女) & 1 $\boldsymbol{\Delta}$ (男) & & 1 & & 2 & 0 & 1 \\
\hline no. 12 & 4 & & 2山(女1) & & 1 & $1 \boldsymbol{\Delta}$ (夫) & & 2 & 1 & 1 \\
\hline no. 13 & 4 & & $1 \mathbf{\Delta}$ (男) & $1 \boldsymbol{\Delta}$ (女） & & $2 \boldsymbol{\Lambda}$ (妻) & & 3 & 0 & 1 \\
\hline no. 14 & 5 & & & 2ム (男女) & & & 3 & 2 & 0 & 3 \\
\hline no. 15 & 4 & 1 & & & $2 \mathbf{\Delta}$ (夫) & & 1 & 1 & 0 & 3 \\
\hline no. 16 & 3 & & & 1 & & & 2 & 0 & 0 & 3 \\
\hline no. 17 & 3 & & $1 \boldsymbol{\Delta}$ (女) & & $1 \mathbf{\Delta}$ (女) & & 1 & 2 & 0 & 1 \\
\hline no. 18 & 4 & & 2山(女1) & & & $2 \boldsymbol{\Lambda}$ (妻) & & 2 & 1 & 1 \\
\hline no. 19 & 4 & 1 & & & $2 \boldsymbol{\Delta}$ (夫婦) & & 1 & 2 & 1 & 1 \\
\hline no. 20 & 4 & & 1 & 1 & & 1 & 1 & 0 & 2 & 2 \\
\hline no. 21 & 4 & & 2ム（女2） & & & 2 & & 2 & 0 & 2 \\
\hline 合計 & 82 & 4 & $22 \boldsymbol{\Delta} 14$ & $11 \mathbf{\Delta} 9$ & $16 \boldsymbol{\Delta} 12$ & $15 \mathbf{\Delta} 8$ & $14 \mathbf{\Delta} 1$ & 45 & 11 & 26 \\
\hline
\end{tabular}

注)現地のアンケート調査による(2010年6月, 9月). 以下の表も同じ

"No. 3の夫 (無職) は子弟の高校進学のために牡丹江市に一緒に転出している. 
2 戸,「就業機会の確保 $\rfloor 0$ 戸といら回答数順位であっ た。また，農地利用権の貸出理由としては，「労働 力不足」 12 戸，「在住者が皆無」6 戸，「健康問題か ら」 2 戸，「転包費をもらら活らが楽」1戸，「農業 での生計維持は不可能」1 戸といら回答であった. 要するに, 出稼ぎや高齢化による農業従事者の不在 が主な貸出理由である。

ところで，H村では，これまで出稼ぎ帰村者は 7 戸（8人）いるが，転出子弟の高学歴化から，今後, 挙家離村する出稼ぎ者は多くなると予想される. No. $1 \sim 6$ は, 両親の出稼ぎ加えて子弟の進学に より全員転出して扬り，すでに実質的には挙家離村 の状沉にある。また，これらの農家世帯員や 60 才 以上世帯員の在住農家 (9戸) の転出子弟は, 将来 的に帰村・帰農することはほぼあり得ないという。 村内では，戸籍を残したまま自宅を売り払って，北 京, 青島や韓国等に挙家離村した農家はすでに 20 戸いる。本村の不在農家（186戸）は全農家の約 67\%を占めて打り，このような多数の長期出稼ぎ者 の挙家離村志向が, 農地利用権を大量に安定的に供 給させていると言えよう。次に, 借地農家の属性や 経営規模の拡大状況について検討してみょう.

\section{4. 借り手農家の属性と稲作所得の高さ}

調査した借地農家は表 2 に示寸 14 戸（世帯員数 59 人）で，そのらち漢族農家が 10 戸と多い。また， 出稼農家が 5 戸あり, 主に経営主の子弟が出稼ぎで 転出している。 また，村外戸籍の借地農家は F1，2，
3， 5 の 4 戸であり，4 ha 以上の耕作面積で村内で は経営規模が大きく，全て借地を契機に隣の T 村 から転居してきた農家であるＨ村内には，このよ らな転住の借地農家が約 30 戸いるという。

14 戸の借地農家は，規模拡大志向の積極性によっ て，「規模拡大型」(上層農）と「自家労働力完全燃 焼型」(中層農) 飞分か子る。前者は，農機投資や 雇用増大で積極的に規模拡大を目指している.さら に，3 ha 以上層の借地志向の $\mathrm{F} 1 ， 2 ， 4 ， 6 ， 7$ と作 業受託志向のF3，10 亿分けられる．2 戸の作業受 託志向農家は，農地利用権の供給がすでに限界に なっていることや転包費の上昇から，機械作業受託 で規模拡大を目指している。

他方，「自家労働力完全燃焼型」は，F10を除く 3 ha 未満農家 6 戸である．当該農家は，既存の自家 労働力で対応できる経営規模に留め, 農機の装備度 は低く田植えや収檴作業は主に手労働で対応してい る. 特に F13，14 は動力農機を所有しない。

な拉，村長によ扎ば，村内農地の借り手農家は 150 戸以上いるが， 5 ha 以上農家は 12 戸に留まり， らち村内在住農家はF1，2の 2 戸のみだという。 また，先述の村民委員会仲介の実績では，村外借地 農家の 1 戸当たり借地面積は 1.2 ha（村内転包面積 $53 \mathrm{ha} /$ 借地農家数 45 戸) である。そして，借地農 家の大半を占める隣村 $\mathrm{T}$ 村農家の平均請負地は約 0.5 ha であるため, 多くの村外借地農家の経営耕地 面積は 2 ha 未満である。このことから，村外農家 を含めて借地農家は「自家労働力完全燃焼型」が大

表 2. 借地農家の経営面積, 農機の所有状況等

\begin{tabular}{|c|c|c|c|c|c|c|c|c|}
\hline $\begin{array}{l}\text { 農家 } \\
\text { 番号 }\end{array}$ & $\begin{array}{c}\text { 経営面積 } \\
\text { (ha) }\end{array}$ & $\begin{array}{c}\text { 請負地 } \\
\text { (ha) }\end{array}$ & $\begin{array}{c}\text { 借地面積 } \\
\text { (ha) }\end{array}$ & 借地志向 & $\begin{array}{l}\text { トラクター } \\
\text { (耕耘機含) }\end{array}$ & 田植え機 & コンバイン & $\begin{array}{l}\text { 世帯員数 } \\
\text { (出稼者)/人 }\end{array}$ \\
\hline $\mathrm{F} 1$ & 7.5 & - & 7.5 & 拡大 & $12 \mathrm{ps}, 48 \mathrm{ps}$ & 4条植 & - & $4(-)$ \\
\hline $\mathrm{F} 2$ & 5.0 & 0.3 & 4.7 & 拡大 & $12 \mathrm{ps} 2$ 台, $54 \mathrm{ps}$ & 4条植 & - & $5(-)$ \\
\hline F3 & 4.5 & - & 4.5 & 縮小 & 65 ps & 4条植 & $35 \mathrm{ps}$ & $6(-)$ \\
\hline $\mathrm{F} 4$ & 4.2 & 0.6 & 3.6 & 拡大 & $12 \mathrm{ps}$ & 4条植 & - & 4(子1) \\
\hline F5 & 4.0 & - & 4.0 & 不変 & $16 \mathrm{ps}, 28 \mathrm{ps}$ & 4 条植 & $80 \mathrm{ps}$ & $3(-)$ \\
\hline $\mathrm{F} 6$ & 3.0 & - & 3.0 & 拡大 & $15 \mathrm{ps}$ & - & 80 ps & 5(子3) \\
\hline F7 & 3.0 & 1.1 & 1.9 & 拡大 & $12 \mathrm{ps}$ & - & - & $4(-)$ \\
\hline $\mathrm{F} 8$ & 2.6 & 0.6 & 2.0 & 拡大 & $12 \mathrm{ps}$ & - & - & $3(-)$ \\
\hline F9 & 2.5 & 0.8 & 1.7 & 不変 & $30 \mathrm{ps}$ & - & - & 4(子2) \\
\hline F10 & 2.5 & 1.0 & 1.5 & 不変 & $15 \mathrm{ps}, 28 \mathrm{ps}$ & - & - & $5(-)$ \\
\hline F11 & 2.0 & 1.0 & 1.0 & 拡大 & $28 \mathrm{ps}$ & - & - & $4(-)$ \\
\hline $\mathrm{F} 12$ & 2.0 & 1.0 & 1.0 & 拡大 & $12 \mathrm{ps}$ & - & - & 4(夫) \\
\hline $\mathrm{F} 13$ & 1.6 & 0.9 & 0.7 & 拡大 & - & - & - & $4(-)$ \\
\hline F14 & 1.5 & 0.6 & 0.9 & 拡大 & - & - & - & 4(子2) \\
\hline
\end{tabular}

注)「世帯員数」の括弧内で(子2) とは, 経営主の子弟 2 名の出稼ぎ者をいう. 
半であり,「規模拡大型」は少数に留まると言える.

また，表 2 で各農家の農業機械の装備状況を見て みると, トラクターと田植機, コンバインの一式装 備は F3，5 のみである. 購入価格に関する回答に よれば, $12 \mathrm{ps}$ の動力耕耘機は約 4 千元, $28 \mathrm{ps}$ の乗 用トラクターは約 2 万元，大型トラクターでは F1 の $48 \mathrm{ps}, \mathrm{F} 5$ の $54 \mathrm{ps}$ で 4 万元，F3 の 65 ps では 9 万 7 千元である. 田植機（4条植え，日本製）は， 導入農家 5 戸 $(\mathrm{F} 1 \sim 5)$ の場合, 1 万 3 千元 2 万 元であった.これに対して，コンバイン（日本製） は高額で, F3 の 35 ps で 11 万元, F5 の 80 ps 9 万元, F6 の $80 \mathrm{ps} 7$ 万 5 千元であった．投資負担の大きさ から, 動力耕耘機に比べて大型トラクタ一, 田植機, コンバインの導入は少数の上層農家に偏っている. これら上層農家は，いずれも機械作業受託を拡大し でり，F5 農家の場合では，2 年前のコンバイン 導入を契機に，収穫作業の受託だけで年間 4 万元の 収入を得ているという。従って，作業受委託を通し て, 村内の稲作は機械化一貫体系が徐々に進展して いる。但し, 小区画の未整備圃場が多く稲作機械化 の進展を阻んで抢り，F1，2，5，10 が小型の動力 耕耘機をも所有する理由になっている。な拈, 籾の 乾燥作業は全て自然乾燥であり, 村内で乾燥機を導 入している農家はいまだ皆無だという。

ここで,「規模拡大型」借地農家の稲作経営の事 例として F2 の場合を取り上げてみよう。当農家は 漢民族籍で，夫婦（共に 48 才・農業従事）と長男 19 才（高校生）は在村し, 長女 24 才（大卒・鷄西 市内勤務）と次女 21 才（大学生）は転出している. $\mathrm{H}$ 村で 95 年から農地借入を始め, しばらくは T 村 から「通勤」（入作）していたが，2006 年の借地拡 大を契機に $\mathrm{H}$ 村に転居してきた。水田面積は, $\mathrm{T}$ 村の水田請負地 0.3 ha と $\mathrm{H}$ 村での借地 4.7 ha の計 5.0 ha である. 経営面積の経過は, 95 年から 04 年 までが 2.0 ha, 05 年 4.0 ha, 06 年に 6.0 ha, 07 年に は自家労働力不足で 1 ha を親戚に委譲し現在の 5.0 haに縮小した. 田植機を 09 年に, 大型トラクター を 10 年に新規に購入している. コンバインは所有 して抢らず，刚取り作業は全て委託している。 09 年の場合，主な生産費は以下の通りである.

(1)種子代 : 品種は「北海道」と「五優稲 1 号」, 播種量 $250 \mathrm{~kg}$ のうち購入 $175 \mathrm{~kg}$, 単価 5.6 元 $/ \mathrm{kg}$ で 計 980 元. (2)耕起・代掻代: 3 日間, 09 年は動力耕
耘機と一部作業委託 (35 元 $/ 10 \mathrm{a})$ で処理していたが, 2010 年購入のトラクター使用を仮定して, 購入金 額 4 万元を 10 年償却で概算し 4,000 元とする. (3) 田植光費用: 手植えが 2.5 ha で 15 人 $\times 2$ 日雇用（人 件費 $100 \sim 150$ 元 $/ 10$ a) で計約 3,000 元，機械田植 は 2.5 ha で, 田植機 1 万 3,000 元の減価償却費を償 却 10 年で 1,300 元 / 年に概算. (4)肥料費: 100 元 $/ 10 \mathrm{a} \times 5$ ha で 5,000 元. (5)農薬費 : 20 元 $/ 10 \mathrm{a} \times$ 5 ha $\times$ 除草剂散布 3 回で 3,000 元. (6)杊り取り：コ ンバイン作業委託（2日間）を委託料 100 元 $/ 10$ a $\times 5$ ha で 5,000 元. (7)農機作業の燃料代 : 各作業 1 ha 当たり約 50 元として（他の作業受託農家の場 合で推計), トラクター, 田植え機, コンバイン作 業で計 750 元. 8)水利費: 20 元 $/ 10 \mathrm{a} \times 5$ ha で 1,000 元. (9)転包費: 3,000 元/ha $\times$ 借地 4.7 ha で 1 万 4,100 元. (10)収穫量 : 単収（籾） $7,500 \sim 8000 \mathrm{~kg} / \mathrm{ha}$ で収 穫量 3 万 $7,500 \mathrm{~kg}$ に概算. (11)販売収入 : 米穀商人に 戋場での生籾販売で, 単価 2.4 元 $/ \mathrm{kg} \times 3$ 万 $7,000 \mathrm{~kg}$ （自家消費 $500 \mathrm{~kg}$ ) で 8 万 8,800 元.

以上の収支からして，販売収入(11) 8 万 8,800 元か ら総生産費（1)～(9)） 3 万 8,130 元を控除すれば, 純収入は約 5 万元, 1 ha 当たりでは約 1 万元になる. な抒，総生産費のうち転包費が 38\%を占める.

同様に, F4 の稲作経営 (4.2 ha らち借地 $3.6 \mathrm{ha}$ ) についても収支を概算してみた。同農家の場合，耕 起・代掻は作業委託で，收穫作業では 2.0 ha 分を自 家労働の手刈り，その他は作業委託である。他の作 業体系や資材投入量, 単収, 価格条件等については, 扣よそF2 の場合と同じである。費目ごとの詳しい 試算経過は省略するが, 販売収入は 7 万 6,680 元, 生産費 2 万 6,280 元であり，純収入（所得）は約 5 万元， 1 ha 当たりでは 1 万 2 千元弱になる。 また， 総生産費に占める転包費の割合は $41 \%$ となる。

上述事例の収支計算は厳密ではなく，借入資本利 子や小農具費等の諸費用, 行政からの種子代補助や 燃料補助金等の収入は考慮していない, その意味で, 算出した所得額は極めて粗い概算結果である. 但し, 上層農家自身においても，1 ha 当たり稲作所得はお よそ 1 万元と見積もって拈り，上記 2 例の概算は農 家自身の現状認識と符合する.

\section{5. 結論}

$\mathrm{H}$ 村の事例分析から, 朝鮮族農村の農地流動化の 
背景と展望を結論づけると以下のようになろう。

まず，農地貸し手側の背景としては，雇用機会が 少ない地域労働市場のもとで, 朝鮮族農民に対する 韓国への渡航条件の緩和や国内遠方大都市での雇用 機会の拡大で, 数年以上に渡る長期出稼ぎを急増さ せた。 また, 出稼ぎの高収入は, 教育費の仕送りを 通して村外転出による子弟の高学歴化を促進し, 挙 家離村（志向）の世帯をも増大させた ${ }^{2}$. これらの 背景が, 農業従事者不在による長期間の農地利用権 の貸出（転包）増大をもたらしたと言えよう。

他方, 農地の借り手側に扎いては次のよらな事情 にあった. H村に隣接する漢族農家が多い T村では, 請負面積が 1 戸当たり $49 \mathrm{a}$ と小さく, しか子低収 益の畑地が大部分（水田は 1 割強）である。また， 農外雇用機会では事故が多発している炭坑労働に限 られている. このよらな事情から, 稲作規模拡大の ための借地志向農家が潜在的に多い。 また， $\mathrm{H}$ 村内 少数の漢族農家は, 韓国出稼ぎよりは賃金水準の低 い国内大都市での出稼ぎに限られるため，借地によ る規模拡大が所得向上のための選択肢になった，そ して，借地農家にとって，現状の米価水準のもとで 稲作所得が高く，小作料を支払っても 1 ha 当たり 1 万元以上の所得を得ることができる.

以上のような貸し手・借り手側双方の事情が， H 村での農地流動化を促進したと言える。その結果, 10 年以上前は村内農家の大多数が 1 ha 規模前後で あったが，朝鮮族農民による大量の離農の一方で， 2 ha 前後の中層農や 3 ha 以上の上層農が形成され

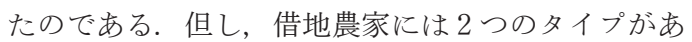
り，農業機械投資や雇用増大で積極的に規模拡大を 目ざす「規模拡大型」(上層農) と, 既存の自家労 働力と機械作業は委託ないし手労働で対応するとい 「「自家労働力完全燃焼型」（中層農）である. 後 者の場合，今後，一部は「規模拡大型」への上昇と ともに, 子弟の出稼ぎを契機に貸し手農家に転化(離 農）する農家が少なくないと予想される.

但し，ヒアリング機会の制約から，調査対象が村 内在住農家に偏って扣り, 以上の結論の妥当性にお いてまだ検証の余地がある。 また, 結論の一般化に は事例研究を積み重衫る必要もある。その意味で, 特に本稿で析出した貸し手の性格や借り手農家の経 営諸類型は, 今後の朝鮮族農村の階層変動分析に打 ける作業仮説として提起するに留めたい.
注 1）表 1 で 20 才未満が 4 人と少ないのだが, 転出者増 大による過疎化の進行のためである. かつて, 郷 内各 3 村に朝鮮族小学校があったが, 児童の激減 で現在では鷄西市内の 1 校に統合している.

2）中国東北の朝鮮族農民の挙家離村志向には, 経済 的条件だけではなく, 彼らの多くが 2 世代前頃か らの北朝鮮，韓国からの移民であることも影響し ているよらに思われる.

\section{参考文献}

［1］山本昌弘・郭 普萍「華北穀作地帯の農民階 層構造一山西省臨汾市吳村鎮一」『農業問題研 究』第 60 号，2007 年 6 月

［2］董彪・菅沼圭輔「中国稲作に打ける大規 模借地経営の存立条件と問題点」『日本農業経 済学会論文集』2010 年度, 2010 年 12 月

３］＼cjkstart史 清華・買生 華「農戸家庭農地要素流動 趨勢及其根源比較」『管理世界』2002 年第 1 期

[4] 洪名 勇「欠発達地区的農地流転分析一来自 貴州省 4 箇県的調査」『中国農村経済』2009 年 第 8 期

［5]池上彰英「内陸農村に打忷農民層分解」, 田 島俊雄編『構造調整下の中国農村経済』東京 大学出版会, 2005 年

［6］菅沼圭輔「〈農業の産業化〉と土地利用再編」, 田島俊雄編『構造調整下の中国農村経済』東 京大学出版会, 2005 年

７］張 忠根 - 史 清華「農地生産率変化及不同 規模農戸農地生産率比較研究一浙江省農村固 定観察点農戸農地経営状況分析」『中国農村経 済』2001 年第 1 期

［8］李豊・原 任利・今井健「穀物主作地 域に打ける出稼ぎ農民の就業と経営変化に関 する実証的研究一中国河南省 S 村を対象とし て一」『農業市場研究』第 19 巻第 1 号, 2010 年 6 月

[9] 馮 鋒 - 杜 加 - 高 牟「基於土地流 転市場的農業補貼政策研究」『農業経済問題』 2009 年第 7 期 